\title{
What Makes Founders Leave Their Companies?
}

\author{
Joon Mahn Lee (Korea University) \\ Dalee Yoon (University of Hawai' $i$ at Mānoa) \\ Steven Boivie (Texas A\&M)
}

\section{KEYWORDS: Management, Startups, IPO, Founders.}

Correctly timing a chief executive officer's (CEO) succession is very important for firms, because CEO transition sends important signals to investors about the future of the firm's strategy and performance. One of the most important CEO succession events is when the founder CEO leaves. These transitions are especially important if the founder has stayed with the firm as the CEO throughout the initial public offering process.

As the experiences with Groupon, Yahoo and Uber show, companies and markets react when a charismatic founder departs. Whether the founder is forced out or leaves voluntarily, companies whose identities are closely intertwined with the founder can feel the effects long afterwards.

Many past studies have attempted to understand involuntary succession: when the founder is forced out during an IPO. Ours focused on understanding why founders might leave voluntarily (https://journals.aom.org/doi/abs/10.5465/amj.2017.009 1) , even when they have survived the IPO with their leadership roles intact. Specifically we ask: What leads to voluntary founder CEO succession?

This is an important practical question, since founder CEOs often have strong control over a firm; serve as its figurehead with employees, customers and investors; and are often identified as a company's legitimate leader. Also, because of that power, the departure of founder CEOs is more likely to be voluntary than involuntary.

Along with affecting a firm and its image with stakeholders, a voluntary departure also has a personal impact. Founders who depart voluntarily after surviving the IPO process can feel profound psychological shock, since their business has become inextricably linked with their self-concept. It may be disconcerting to find out that other entities now call the shots. As one founder pointed out to us: "Once the firm becomes public, you are not able to fully control your firm. As a CEO, I spend most of the time talking to and following the requests of outside shareholders and analysts. I realized that, once the firm goes public, my firm became their firm."

\section{What we studied}

To study voluntary founder CEO succession, we focused on understanding factors that reflect founder CEOs' psychological attachment to their firms. We argue in our paper that the higher the founder CEO's psychological attachment to the firm, the less likely it will be that he or she will leave. We looked closely at the factors that may increase founder CEOs' psychological attachment to the firm, to better understand the timing of founder CEO succession.

Using a sample of newly listed public firms in the US from 2000 to 2013, we studied this question in detail. We identified 1396 firms that had participated in an IPO over this time period. Of those firms, 448 of them were still run by founder CEOs at the timing of IPO and, among these firms, 123 firms experienced succession events after IPO.

Because we were interested in voluntary turnover, it was important for us to correctly categorize whether the 123 succession events were voluntary or involuntary. To do this, we collected detailed information about each founder CEO's departure and the departure's circumstances. We gathered information from multiple sources including SEC filings, databases, earnings announcements, firm press releases, media reports, and news articles. We then used these sources to determine the reasons for each turnover event. In our sample we determined that 88 of the departures were voluntary - involving retirement, starting a new firm, or transitioning from serving as the CEO to being a board member.

We then focused on a set of factors that indicate a 
founder CEO's attachment to the firm. We looked at four factors: the CEO's prior entrepreneurial experience; the number of cofounders; whether the CEO was a core founder; and the length of time that the firm was private. We found that the as the first two factors increased (e.g., prior entrepreneurial experience and the number of cofounders), they were associated with a founder being more likely to leave voluntarily. Conversely, we also found that the second two factors (e.g. being a core founder and more years as a private firm) were associated with the founder being less likely to leave voluntarily, as they increased the founders' sense of attachment to the firm.

\section{Takeaways}

Our study provides some important practical implications for firm stakeholders, including investors, boards of directors and the CEOs themselves.

First, our study suggests that the firm's leadership transition may not only be the result of well-planned decisions, but also may be a consequence of psychological attachment. For example, several public firms, including Groupon, Yahoo, Uber, and Lululemon, experienced difficulties in their transitions from founder CEOs to professional CEOs. So understanding how a founder CEO's attachment plays a role in this process may help investors better predict when to expect these types of exits. It can also encourage company boards to develop a succession plan that minimizes the risk of a "political fight" between a founder CEO and other shareholders.

Second, shareholders should understand that the founder's attachment to the firm could be a doubleedged sword for firm performance. It is possible that the founder's attachment can lead to the founder CEO behaving altruistically and lower agency problems when making firm-level decisions (e.g., use of expensive perquisites such as private jets). However, it may also increase the risk of impeding the firm from hiring appropriate leadership at an important time.

\section{Read More}

Lee, J., Yoon, D., and Boivie, S., Founder CEO Succession: The Role of CEO Organizational Identification, Academy of Management Journal (https://journals.aom.org/doi/abs/10.5465/amj.2017.009 1) , February 2020 